\title{
Articles
}

Central European Review of Economics \& Finance

Vol. 22, No. 6 (2017), pp. 17-27. D0I: 10.24136/ceref.2017.024

\author{
Małgorzata Lotko', Magdalena Paździor², Piotr Paździor³, \\ Aleksander Lotko ${ }^{4}$, Marcin Nowak ${ }^{5}$, kukasz Wójtowicz ${ }^{6}$
}

\section{EVALUATION OF THE QUALITY OF BANKING SERVICES WITH THE USE OF THE SERVPERF METHOD}

The purpose of this paper is to measure and evaluate the quality of banking services with the use of the SERVPERF method. The questionnaire method was applied in the study. The questionnaire was composed of two parts. The first part covered certificate questions specifying the customers of the bank and the second substantial part included the questions of the SERVPERF questionnaire. The author of this paper has studied merely the quality performance pursuant to the assumption of the SERVPERF method adopting the expectations of the customers at the maximum level.

The analysis of the results of the carried out study demonstrates that the biggest quality gap was observed for the dimension tangibles. The study of diversification showed that tangibles, empathy and responsiveness are diversified only by one factor. Education of the respondents was a variable that diversified the greatest number of dimensions.

JEL Classification Codes: C38, M31.

Keywords: quality, banking services, SERVPERF.

\footnotetext{
${ }^{1}$ Associate Professor, Ph.D., K. Pulaski University of Technology and Humanities in Radom, Faculty of Economics and Legal Sciences.

${ }^{2}$ Assistant Professor, Ph.D. Eng., K. Pulaski University of Technology and Humanities in Radom, Faculty of Materials Science and Design.

${ }^{3}$ Eng., Warsaw University of Life Sciences - SGGW, Faculty of Human Nutrition and Consumer Sciences.

${ }^{4}$ Associate Professor, Ph.D., K. Pulaski University of Technology and Humanities in Radom, Faculty of Economics and Legal Sciences.

${ }^{5}$ M.A., Ph.D. student, K. Pulaski University of Technology and Humanities in Radom, Faculty of Economics and Legal Sciences.

${ }^{6}$ M.A., Ph.D. student, K. Pulaski University of Technology and Humanities in Radom, Faculty of Economics and Legal Sciences.
} 


\section{Introduction}

Development of today's global economy triggered by technological progress, liberalization of trade, reduction of costs of transportation and automation of production changes the operation model of numerous organizations. Today we are observing the evolution from traditional industries to service and innovative industries. One of the key phenomena is dematerialization of production. This leads to the expansion of the services sector (Ulbrych, 2016). In Poland the contribution of the services sector in the creation of the added value and the National Gross Product amounted to 67.3\% in 2015 (MG, 2015), and in the entire European Union it exceeded 73.6\% (Eurostat, 2015). However, at the same time, we may observe certain marginalization of the services issues present in the sphere of the theory (Dąbrowska, 2008; Rogoziński, 2003; Szymańska, 2015). Thus, these issues are worth discussing.

These days, the services sector is an area of the economy in which the entities are conducting their businesses within the area of the provision of services (PARP, 2005). This sector covers various industries and branches, the number of which changes together with its development. This makes the above described sector heterogeneous. The main characteristic feature of the services sector is the fact that its development, and at the same time, the participation in the economy, is increasing. Services, similar to the products, are the object of the turnover in the market. Their characteristic features determine their competitiveness among other sectors.

Banking services are specific, because they connect all of the participants of the trade exchange. In this particular case both product manufacturers and services providers are at the same time the customers of financial institutions.

Measurement and evaluation of the quality of services is not an easy task. It is proved by the increasing popularity of this subject in the global literature and the establishment of competing conceptual models (specifying the attributes of the quality and relations between them) and measurement models (suggesting the manners and tools used for the purposes of the measurement). In this study we applied the version of the method, which despite its imperfections, is a kind of a universal standard of the measurement and evaluation of the quality of services.

The purpose of this paper was to measure and evaluate the quality of banking services with the use of the SERVPERF method. 


\section{Characteristic of banking services}

Provision of banking services is connected with the form assumed by the money and its function. A contemporary bank must meet the requirements of the economy based on the knowledge, in which the services play the dominant role. The symptoms of the satisfaction of these requirements are the modern market offers of the banks, individual customer service as well as advisory in skilful shaping of financial resources, whose aim is to provide satisfactory effectiveness of the activities taken up by an individual, as well as to contribute to the increase of the sense of security against the loss of the resources. The economic function of the banks in the market is a very crucial element driving the improvement of banking services which are no longer treated as the entities operating in the oligopolistic markets. There is a dominant conviction that they are functioning in highly competitive markets, where the battle for the customer is the most important issue (Korenik, 2006). Extra-economic aspects were also noticed. They are directly shaping the form of banking services such a technological progress of particular countries, culture and social stratification as well as political and legal decisions. The quality of modern banking services, the level of which depends on a number of factors, is a fundamental distinguishing feature of banks' competitiveness.

In the light of the theory of quality based management, the customer should always be in the centre of interest of banks and other organizations. It is even more important due to the fact that the characteristics of the provision of banking services is connected with the fact that they are not disposable or short-term, but the contact with the customer may last many years. Thus, every evaluation of their quality is based on the values worked out in a long-term perspective and so it may be subjective.

The subsequent element worth mentioning is the adjustment of the banks to the changes taking place in their external environment, among others the changes of customers preferences, places of residence, political decisions forcing the increase of the prices of the provision of banking services or the changes connected with the specificity of a given kind of services. For example, when a bank offers its customers the extension of the offer of the current and savings account and adds a special service connected with a vehicle or real estate insurance, a part of the customers will read it as the improvement of quality, but the other part will criticise the idea due to the fear for the increase of the costs of hitherto cooperation (Opolski, 2000). 
Therefore subjectivity of evaluations connected with the approach to the customer presented by the bank cannot be entirely avoided.

It is also emphasized that the improvement of the quality of services contributes to the increase of profit. This phenomenon comprises of two stages. Firstly, the attachment of bank's customer by way of the efforts connected with the improvement of the services is a priority, what as a consequence results in the enhancement of customers' satisfaction, and at the same time the said attachment becomes stronger. The second stage consists in keeping the customer. To make this happen, the customer must be provided with the lowest level of quality so that transferring the account to the other bank is not seem to be lucrative (Zaleska, 2008). This strategy allows for the optimisation of the expenses for the quality, both in order to attract new customers, and to reduce the outflow of those that have already been acquired.

There is a number of determinants of the level of quality and it depends on the policy implemented by a given bank. However, the common denominator for all institutions belonging to this particular industry, is the conviction that a customer is the key for every decision and customer's loyalty determines the success of the bank.

\section{Method of the studies}

SERVPERF (Service Performance) is a method established in response to the criticism of the assumptions related to the SERVQUAL model, concerning the measurement of both quality performance and expectations of performance. The basis of the concept created by J. Cronin and S. Taylor is the understanding of quality in its traditional interpretation as a perfection of performance - ideal quality. Therefore the authors of the method recommend examining the quality of a provided service and then referring the said service to the ideal state (Cronin and Taylor, 1994). Therefore the measurement of the expectations of customers was eliminated in this concept due to the probability of existence of maximum expectations in relation to the analysed criteria.

In SERVPERF model, the measurement and evaluation of the quality of services may be realized on the basis of a set of factors covered by the SERVQUAL concept (Stoma, 2012). Pursuant to this concept the respondents aiming to take advantage of a given service for the first time should be selected, then asked to fill in a questionnaire of the evaluation of quality expected prior to taking advantage of a service and finally the respondents should be 
asked to answer questions concerning the quality after taking advantage of a given service.

A study carried out according to the guidelines established by J. Cronin and $\mathrm{S}$. Taylor is at the same time less complicated and less time-consuming when compared to the SERVQUAL method study (Gilmore, 2003). Obtained results are much more restrictive and objective.

A study was carried out with the use of a questionnaire method. The questionnaire was composed of 28 positions. The first part included demographics questions which constituted a formal characteristic of respondents i.e. consumers in analysed industries. The second part, the substantial one, included 22 SERVQUAL questionnaire statements. However, merely the provision of quality was taken into consideration as pursuant to the assumptions of SERVPERF method, expectations should be adopted at the maximum level.

The selection of the sample was of purposive nature. The study covered hundred customers taking advantage of bank services. The number of the sample may be deemed as sufficient taking into account the fact that a great number of researchers in the quality and marketing area suggests the sufficiency of a total sample $n=200$ for even more complex measurement tools than the ones suggested in this paper (Ford, Walker and Churchil, 1975; Saxe and Weitz, 1982), including 40 respondents in each category of services (Parasuraman, Zeithaml and Berry, 1988).

The study was carried out in the period from $12^{\text {th }}$ to $25^{\text {th }}$ November 2016.

On account of demographic variables, a non-parametrical Kruskal-Wallis test was applied for the purposes of verification of statistical hypotheses concerning diversification of evaluations of particular quality dimensions between the distinguished groups. In this test, a zero hypothesis assumes that the samples originate from a population of the same Dispersion, while the alternative hypothesis states that they originate from different Dispersions. It may be described as follows:

$\mathrm{H}_{0}$ : Dispersion of a variable is the same for all codes of the grouping factor regarding the alternative hypothesis;

$\mathrm{H}_{1}$ : Dispersions of a variable for at least two codes of the grouping factor vary.

A consequence of the adoption of $\mathrm{H}_{0}$ hypothesis, is the statement that the levels of the studied factor (groups) do not have any significant impact on the observed results. Similarly, a consequence of rejecting $\mathrm{H}_{0}$ hypothesis is the statement that the levels of studied risk significantly influence the observed results. It is then stated that a given factor diversifies the results (Skrzypek (ed.), 2013). Kruskal-Wallis test is appropriate in the case, where at least 3 codes of a grouping variable are observed. In the case, where 
there are only 2 codes of the grouping variable, the $U$ Mann-Whitney test is applied. In this case, zero hypothesis assumes that the averages are equal for both groups regarding the alternative hypothesis according to which the said averages vary.

a)

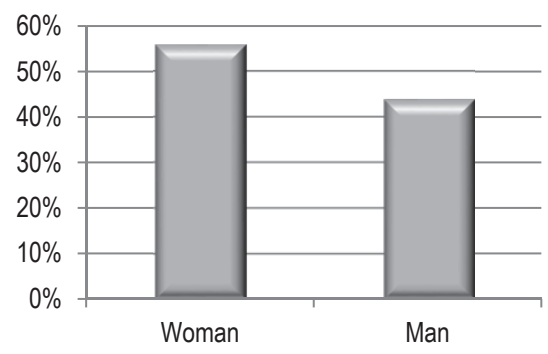

c)

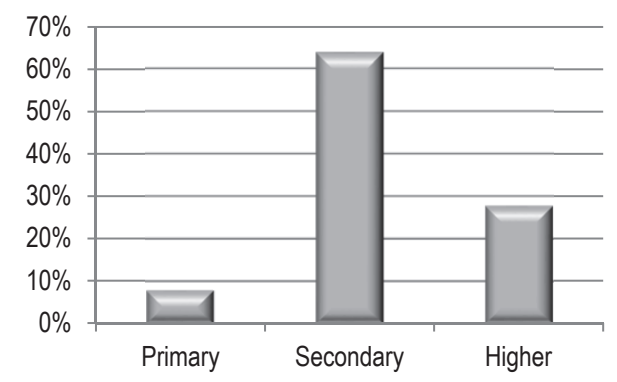

e)

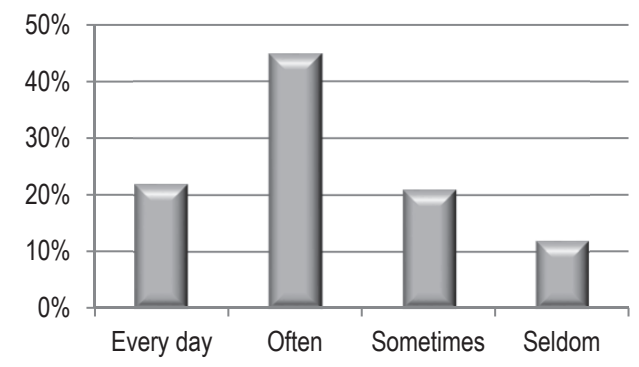

b)

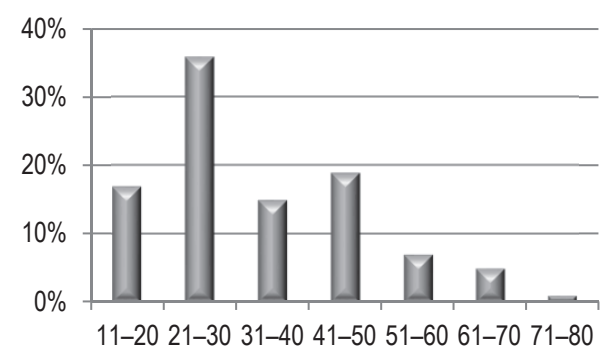

d)

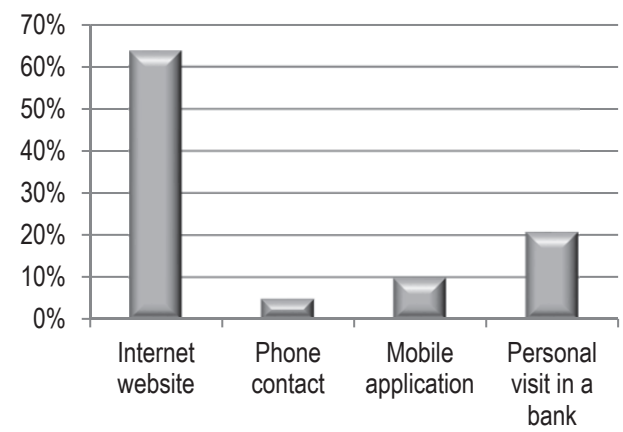

f)

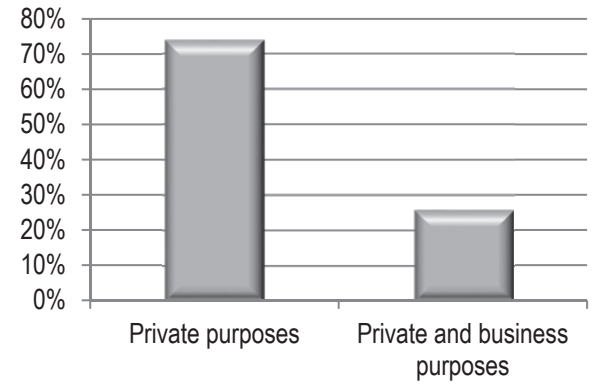

Figure 1. Layouts of sample characteristics: (a) sex, (b) age, (c) education, (d) manner of taking advantage of banking services, (e) frequency of taking advantage of banking services, (f) purpose of taking advantage of banking services.

Source: author's study. 


\section{Discussion on the results of the study}

Figure 2 presents quality gaps identified in line with the assumptions of SERVPERF method.

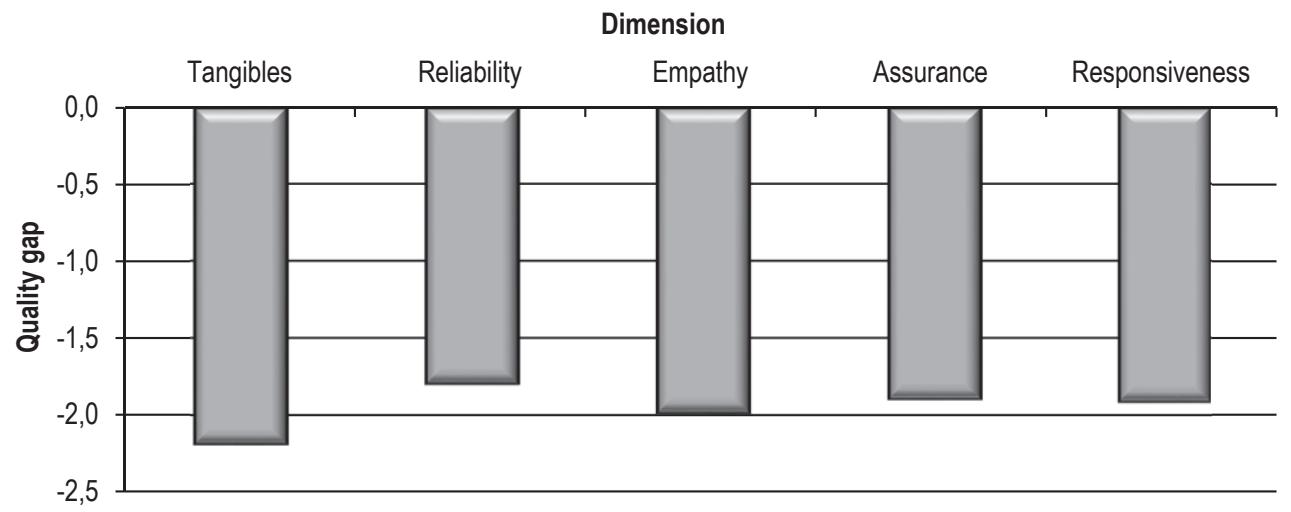

Figure 2. Values of quality gaps

Source: author's study.

Figure 2 demonstrates that the greatest discrepancy for researched dimensions between the quality level of a provided service and the ideal state has been noted for the dimension tangibles (average value of the gap amounted to -2.18), whereas the lowest value has been recorded for the dimension reliability (average value of the gap amounted to -1.79). It is worth remarking that for all dimensions, the indicated quality gap exceeded the value of 1.5 and this proves a relatively large discrepancy between the actual state of the quality of banking services and the level of their ideal quality.

Carried out study also proved that the recipients of banking services, evaluated the parameter of the quality of banking services representing the dimension - empathy at the highest level - individual treatment (5.32) and parameters within the scope of the dimension reliability - perfect registration of documents (5.28) and timeliness of service (5.27). All researched variables were found in the range $<4.65 ; 5.32>$. Variables within the scope of the elements of visual identification of an organization - attractiveness of buildings and surroundings (4.65), advertising materials connected with the provision of a service, were evaluated at the lowest level (4.7) (Lotko, Paździor, Nowak and Wójtowicz, 2017).

Table 1 presents a set of values of quality gaps for particular dimensions. 
Table 1. Collective set of the values of quality gaps for particular dimensions

\begin{tabular}{|c|c|c|c|c|c|}
\hline \multirow{2}{*}{ Variable } & \multicolumn{5}{|c|}{ Value of the quality gap for particular dimensions } \\
\hline & Tangibles & Reliability & Empathy & Assurance & Responsiveness \\
\hline \multicolumn{6}{|c|}{ Sex of respondents } \\
\hline Women & -2.14 & -1.72 & -2.00 & -1.88 & -2.06 \\
\hline Men & -2.23 & -1.88 & -1.95 & -1.90 & -1.72 \\
\hline \multicolumn{6}{|c|}{ Age of respondents (years) } \\
\hline $11-20$ & -1.69 & -1.21 & -1.67 & -1.63 & -1.99 \\
\hline $21-30$ & -1.98 & -1.51 & -1.79 & -1.60 & -1.67 \\
\hline $31-40$ & -2.77 & -2.31 & -2.43 & -230 & -2.12 \\
\hline $41-50$ & -2.78 & -2.48 & -2.44 & -2.51 & -2.18 \\
\hline $51-60$ & -2.04 & -1.86 & -1.80 & -1.68 & -2.29 \\
\hline $61-70$ & -1.85 & -1.84 & -1.88 & -1.75 & -1.45 \\
\hline $71-80$ & -0.50 & 0.00 & -0.20 & -1.00 & -0.25 \\
\hline \multicolumn{6}{|c|}{ Education of respondents } \\
\hline Primary & $-1,53$ & -1.20 & -0.73 & -1.03 & -0.88 \\
\hline Secondary & $-2,04$ & -1.70 & -1.98 & -1.84 & -2.01 \\
\hline Higher & $-2,71$ & -2.16 & -2.33 & -2.25 & -1.97 \\
\hline \multicolumn{6}{|c|}{ Ways of using banking services } \\
\hline Internet Website & -2.19 & -1.74 & -1.98 & -1.82 & -1.84 \\
\hline Telephone contact & -2.40 & -2.08 & -2.32 & -2.15 & -2.15 \\
\hline Mobile application & -2.75 & -2.54 & -2.68 & -2.93 & -2.40 \\
\hline Personal visit in a bank & -1.85 & -1.51 & -1.55 & -1.56 & -1.83 \\
\hline \multicolumn{6}{|c|}{ Frequency of using banking services } \\
\hline Every day & -2.17 & -1.72 & -2.28 & -2.17 & -1.97 \\
\hline Often & -2.36 & -1.99 & -2.09 & -1.93 & -2.05 \\
\hline Sometimes & -2.18 & -1.63 & -1.76 & -1.80 & -1.71 \\
\hline Seldom & -1.56 & -1.47 & -1.38 & -1.40 & -1.60 \\
\hline \multicolumn{6}{|c|}{ Purpose of using banking services } \\
\hline Private purposes & -2.15 & -1.77 & -1.95 & -1.87 & -1.92 \\
\hline $\begin{array}{l}\text { Private and business } \\
\text { purposes }\end{array}$ & -2.28 & -1.84 & -2.06 & -1.94 & -1.88 \\
\hline
\end{tabular}

Source: author's study.

The analysis of data included in table 2 proves that the highest (-2.77) value of the gap for the dimension tangibles was indicated by the respondents at 31-40 years of age, whereas the oldest age group indicated the smallest gap (-0.5). When observing the results for the dimension reliability, it should be marked that the greatest discrepancy between the obtained value and the 
ideal level of quality was indicated by the users taking advantage of banking services via a mobile application (-2.54). For the respondents of the youngest and the oldest age group, we proved the lack of discrepancies between the ideal level of quality and real quality - quality gap for this dimension was the lowest one. Within the area of empathy, it is stated that the highest value of the gap was indicated by the persons using banking services by way of mobile applications (-2.68) and at 41-50 years of age (-2.44), whereas the smallest gap was recorded in the opinion of the oldest group of respondents $(-0.2)$ taking advantage of the services rarely $(-1.38)$ and those, who prefer personal contact in the headquarters of the bank (-1.55). In the dimension assurance, the greatest gap was detected, similar as in the dimension empathy, among the users of banking applications (-2.93). The smallest gaps within this scope was indicated by the oldest respondents and persons who completed primary education, The highest value of the gap (-2.40) for the dimension responsiveness was stated among the respondents using banking services through mobile application and smallest gap (-0.25) among the oldest group of respondents and with an average level of education (-0.88).

Table 2 presents statistically significant diversification of the evaluation of quality dimensions in respect of particular certificate variables.

Table 2. Statistically significat diversifications of the evaluation of quality dimension in respect of particular certificate variables

\begin{tabular}{|l|c|c|c|c|c|}
\hline \multirow{2}{*}{$\begin{array}{c}\text { Diversifying } \\
\text { factor* }\end{array}$} & \multicolumn{5}{c|}{ Quality dimension } \\
\cline { 2 - 6 } & Tangibles & Reliability & Empathy & Assurance & Responsiveness \\
\hline Sex & 0.8161 & 0.7865 & 0.6922 & 0.5072 & 0.0795 \\
\hline Age & 0.1744 & 0.1685 & 0.6103 & 0.2031 & 0.5136 \\
\hline Education & $0.0297^{*}$ & 0.2077 & $0.0013^{*}$ & 0.0741 & $0.0237^{*}$ \\
\hline $\begin{array}{l}\text { Way of using } \\
\text { banking services }\end{array}$ & 0.3298 & 0.3868 & 0.1964 & 0.1690 & 0.7255 \\
\hline $\begin{array}{l}\text { Frequency of using } \\
\text { banking services }\end{array}$ & 0.2269 & 0.7233 & 0.1408 & 0.4752 & 0.6947 \\
\hline $\begin{array}{l}\text { Purpose of using } \\
\text { banking services }\end{array}$ & 0.5414 & 0.6423 & 0.8687 & 0.8161 & 0.9591 \\
\hline
\end{tabular}

* at the level of significance $\alpha=0,05$.

Source: author's study.

The analysis of table 2 demonstrates that merely the education of respondents was a variable that diversified three dimensions: responsiveness, empathy and tangibles. 


\section{Summary}

The analysis of data based on the profile of customers using banking services provides a statement that the highest value $(-2.78)$ of the gap was indicated by the respondents at $41-50$ years of age. This results reflects the requirements in respect of the dimension tangibles.

No positive value of the quality gap was observed. The only zero value of the gap was recorded for the dimension reliability. This means that the level of the obtained quality of banking services for the oldest group of respondents was equal to the level of ideal quality.

Women evaluated the dimension reliability at the highest level (-1.72), whereas men opted for responsiveness (-1.72). In the opinion of the oldest group of respondents, the smallest quality gaps were recorded within the scope of all studied dimensions. While the group of respondents at 41-50 years of age indicated the highest values of quality gaps.

Persons who completed primary education evaluated the provided banking services at the highest rates. It is evidenced by the lowest values of recorded quality gaps within the scope of all dimensions in this particular group of respondents.

A personal visit in a bank is one of the ways of using banking services. According to the opinion of respondents, the quality level of such a personal visit proved to be very close to the ideal quality - the smallest gap for the dimension reliability (-1.51). On the other hand, due to the frequency of using banking services, the respondents who use such services rarely, recorded the lowest values of quality gaps in all measured dimensions. The recipients of banking services for personal and business purposes indicated the largest quality gap for the dimension tangibles (-2.28), whereas the smallest gap between the obtained value and the ideal value was observed for the respondents using banking services merely for private purposes for the dimension reliability $(-1.77)$.

A factor which significantly diversified three criteria was the education of the recipients of baking services. A diversification may be spread among the entire population only for this particular factor. 


\section{References}

Cronin J. Taylor S. (1994). SERVPERF versus SERVQUAL: Reconciling performance-based and perceptions minus expectations measurement of service quality. „Journal of Marketing”, Vol. 58, No. 1.

Dąbrowska A. (2008). Rozwój rynku usług w Polsce - uwarunkowania i perspektywy. Wyd. SGH: Warszawa.

Drożdż W., Pluciński M. (2005). Międzynarodowa wymiana usług, (w:) Flejterski S. i inni (red.), Współczesna ekonomika usług. PWN: Warszawa.

Eurostat (2015). Rachunki narodowe i PKB. http://ec.europa.eu/eurostat/ (dostęp 04.01.2017).

Ford N., Walker O., Churchill G. (1975). Expectation-Specific Measures of the Intersender Conflict and Role Ambiguity Experienced by Industrial Salesmen. „Journal of Business Research”, No. 3.

Gilmore A. (2003). Services Marketing and Management. Sage: London.

Korenik D. (2006). Innowacyjne usługi banku. PWN: Warszawa.

Lotko M., Paździor M., Nowak M., Wójtowicz Ł. (2017). Pomiar jakości usług. Wybrane zastosowania metody SERVQUAL. Instytut Naukowo-Wydawniczy Spatium: Radom.

MG (2015). Polska 2015. Raport o stanie gospodarki. Ministerstwo Gospodarki: Warszawa.

Opolski K. (2000). Jakość w banku. W praktyce i teorii zarządzania. CeDeWu: Warszawa.

Parasuraman A., Zeithaml V., Berry L. (1988). A conceptual model of service quality and its implications for future research. „Journal of Marketing”, Vol. 49.

PARP (2005): Innowacje i transfer technologii - słownik pojęć. PARP: Warszawa.

Rogoziński K. (2003). Cywilizacja usługowa: samorealizujące się niespełnienie. Wydawnictwo Akademii Ekonomicznej w Poznaniu: Poznań.

Saxe R., Weitz B. (1982). The SOCO Scale: A Measure of the Customer Orientation of Salespeople. „Journal of Marketing”, No. 19.

Skrzypek E. (red.) (2013). Dojrzałość jakościowa a wyniki przedsiębiorstw zorientowanych projakościowo. Difin: Warszawa.

Stoma M. (2012). Modele i metody pomiaru jakości usług. Q\&R, Polska: Lublin. Szymańska E. (2015). Serwicyzacja gospodarki jako źródło jej transformacji. „Optimum. Studia Ekonomiczne”, nr 1 (73).

Ulbrych M. (2016), Serwicyzacja produkcji przemysłowej. Wnioski dla Polski. „Finanse, Rynki Finansowe, Ubezpieczenia”, nr 3 (81).

Zaleska M. (2008), Współczesna bankowość. Tom I, Difin, Warszawa. 